\title{
Neopolystoma liewi sp. n. (Monogenea: Polystomatidae) from the eye of the Malayan box turtle (Cuora amboinensis)
}

\author{
Louis H. du Preez ${ }^{1}$ and L.H.S. Lim ${ }^{2}$
}

\author{
${ }^{1}$ Department of Zoology and Entomology, University of the Free State, P.O. Box 339, Bloemfontein 9300, South Africa; \\ ${ }^{2}$ Institute of Biological Sciences, University of Malaya, 50603 Kuala Lumpur, Malaysia
}

Key words: Polystomatidae, Neopolystoma, Cuora amboinensis

\begin{abstract}
Neopolystoma liewi sp. n. is described from the conjunctival cavity of the Malayan box turtle Cuora amboinensis (Daudin, 1802), in Peninsular Malaysia. This is the first record of Neopolystoma in Malaysia and the fourth polystomatid species described from $C$. amboinensis. Of the 27 Malayan box turtles examined, 8 were found to be infected. A maximum of 2 parasites per eye and 4 individuals per host was recorded. $N$. liewi $\mathrm{sp}$. n. differs from all other members of the genus by possessing few and short genital spines and small marginal hooks. The oncomiracidium has 64 ciliated cells arranged symmetrically about the sagittal axis.
\end{abstract}

Polystomatids are mainly parasites of semi-aquatic vertebrates. The majority are parasitic in anurans but they are also found in a Japanese salamander (Onychodactylus japonicus), the Australian lungfish (Neoceratodus forsteri), aquatic chelonians and the African hippopotamus (Hippopotamus amphibius) (see Yamaguti 1963, Reichenbach-Klinke 1966, Stunkard 1924, respectively).

Yamaguti (1963) created the subfamily Polystomoidinae for the polystomatids of chelonians which are represented by three genera namely Polystomoides Ward, 1917, Polystomoidella Price, 1939 and Neopolystoma Price, 1939. In Peninsular Malaysia the Polystomoidinae are represented by six species belonging to two genera: Polystomoides malayi Rohde, 1963 and Polystomoidella mayesi Richardson et Brooks, 1987 from the urinary bladder of Cuora amboinensis; Polystomoides asiaticus Rohde, 1965 from the oral cavity of C. amboinensis; Polystomoides siebenrockiella Rohde, 1965 from the urinary bladder of Siebenrockiella crassicollis; Polystomoides renschi Rohde, 1965 from the oral cavity of S. crassicollis; and Polystomoides platynotae Combes et Rohde, 1979 from the oral cavity of Notochelys platynotae.

This paper reports the finding of a new species of Neopolystoma from the conjunctival cavity of the Malaysian box turtle, Cuora amboinensis (Daudin, 1802). It is also the first record of Neopolystoma in Malaysia and represents the fourth polystomatid genus to be described from $C$. amboinensis.

\section{MATERIALS AND METHODS}

During April 1998 three Malayan box turtles (Cuora amboinensis) were collected in a small pond in the Botanical Garden (Hutan Rimba), on the campus of the University of Malaya in Kuala Lumpur and 9 other specimens from a pet shop in Kuala Lumpur. During May 199915 Malayan box turtles were obtained from pet shops in Kuala Lumpur. The chelonians from the pet shops were collected in the Perak area.

The chelonians were placed individually in plastic aquaria $(400 \mathrm{~mm} \times 250 \mathrm{~mm})$ with water to a depth of $60 \mathrm{~mm}$. The water in which the chelonians were kept was screened for parasite eggs every second day over a period of 8 days. The water was sieved through a set of three plankton net sieves of mesh sizes $500 \mu \mathrm{m}, 250 \mu \mathrm{m}$ and $112 \mu \mathrm{m}$. The $500 \mu \mathrm{m}$ sieve let all the eggs through but removed all the larger particles from the water. Contents from each sieve were transferred to glass Petri dishes and eggs, if any, were picked out from the debris. Eggs of the new species were distinguished from eggs laid by Polystomoides sp. infecting the same host by their elliptical shape (see below). The eggs were transferred to small glass Petri dishes containing dechlorinated tap water and incubated at $30-37^{\circ} \mathrm{C}$. Difficulty was experienced with the incubation of the eggs of the new species of Neopolystoma and only two oncomiracidia were hatched. Both larvae were stained in silver nitrate (Lynch 1933). Stained preparations were rinsed in distilled water, dehydrated in an ethanol series, cleared in xylene and mounted in Canada balsam. Measurements of larval sclerites are based on these silver-stained preparations.

Infected chelonians were killed with an injection of sodium pentabarbitone (Euthapent) and dissected. The urinary and accessory bladders, cloaca, oral and pharyngeal cavities, nasal cavities and eyes were carefully examined for the presence of polystomatids.

A total of 19 specimens was obtained from the eyes of $C$. amboinensis. Twelve of the parasites were fixed flattened in $10 \%$ neutral buffered formalin for preparation of whole mounts. Eleven of these were egg-producing. The remaining 7 specimens were fixed for molecular, histological and electron microscope studies which do not form part of the present study. Flattened specimens were stained in alum carmine and mounted permanently in Canada balsam. However, prior to staining, the specimens were cleared in Bouin-glycerin and studied under phase contrast. The sclerotised structures were 
examined and drawn before staining and mounting. Description is based on egg-producing parasites. All measurements (mean with range in parentheses) are given in micrometres $(\mu \mathrm{m})$.

\section{RESULTS}

\section{Levels of infection}

Two of the three hosts collected in the Botanical Garden on the campus of the University of Malaya were infected (prevalence, 67\%; mean intensity, 2.5). Six of the 24 hosts purchased from the pet shops were infected (prevalence, 25\%; mean intensity, 2.3). The highest infection in a single host, which was collected on the campus, was 4 parasites and the highest infection per eye was 2 parasites.

\section{Neopolystoma liewi sp. n.}

Figs. 1-3

$\mathrm{T}$ y $\mathrm{p}$ e $\mathrm{h}$ o s t : Cuora amboinensis (Daudin, 1802), the Malayan box turtle.

S i t e : Conjunctival cavity, under the lower eyelid.

T y p e 1 o c a 1 i t y: Well vegetated earth-walled dam in the Botanical Garden (Hutan Rimbat) on the campus of the University of Malaya, Kuala Lumpur, Malaysia.

$\mathrm{T}$ y $\mathrm{p}$ e $\mathrm{m}$ a $\mathrm{t}$ e $\mathrm{r}$ i a 1 : Eleven mature and egg-producing. Holotype (1999.10.29.1) and three paratypes (1999.10.29.2-4) deposited in the Parasitic Worms Collection, Natural History Museum, Cromwell Road, London SW7 5BD, United Kingdom; one paratype (M$355)$ in the collection of the Institute of Parasitology, Academy of Sciences of the Czech Republic, Branišovská 31, 37005 České Budějovice, Czech Republic; six paratypes (NMB P222 - NMB P227) in the Parasitic Worm Collection, National Museum, Aliwal Street, Bloemfontein 9301, South Africa.

E t y m o lo g y : The species name liewi refers to Mr Liew Kim-Seng George as an acknowledgement of his invaluable assistance and support during this research project.

\section{Description (based on 11 specimens)}

Mature parasite (Fig. 1). The general characteristics of mature parasites are typical of Neopolystoma Price, 1939 in that they infect turtles and do not have hamuli. Body elongate; total length 3474 (2120-4169); greatest width 1321 (1012-1566); width at vaginae 1246 (10121446); haptor length 921 (795-1205); haptor width 1179 (988-1470); haptoral sucker diameter 217 (184-252). Suckers well developed.

Mouth subterminal, ventral. Oral sucker 367 (252446) wide; pharynx length 349 (296-398); pharynx width 382 (330-417). Intestine bifurcate, caeca not confluent posteriorly, more or less of equal length; extends well beyond posterior margin of testis but not into haptor; caeca without diverticula.

Single testis roughly circular, length 341 (271-446) and width 363 (349-436); seminal vesicle prominent.

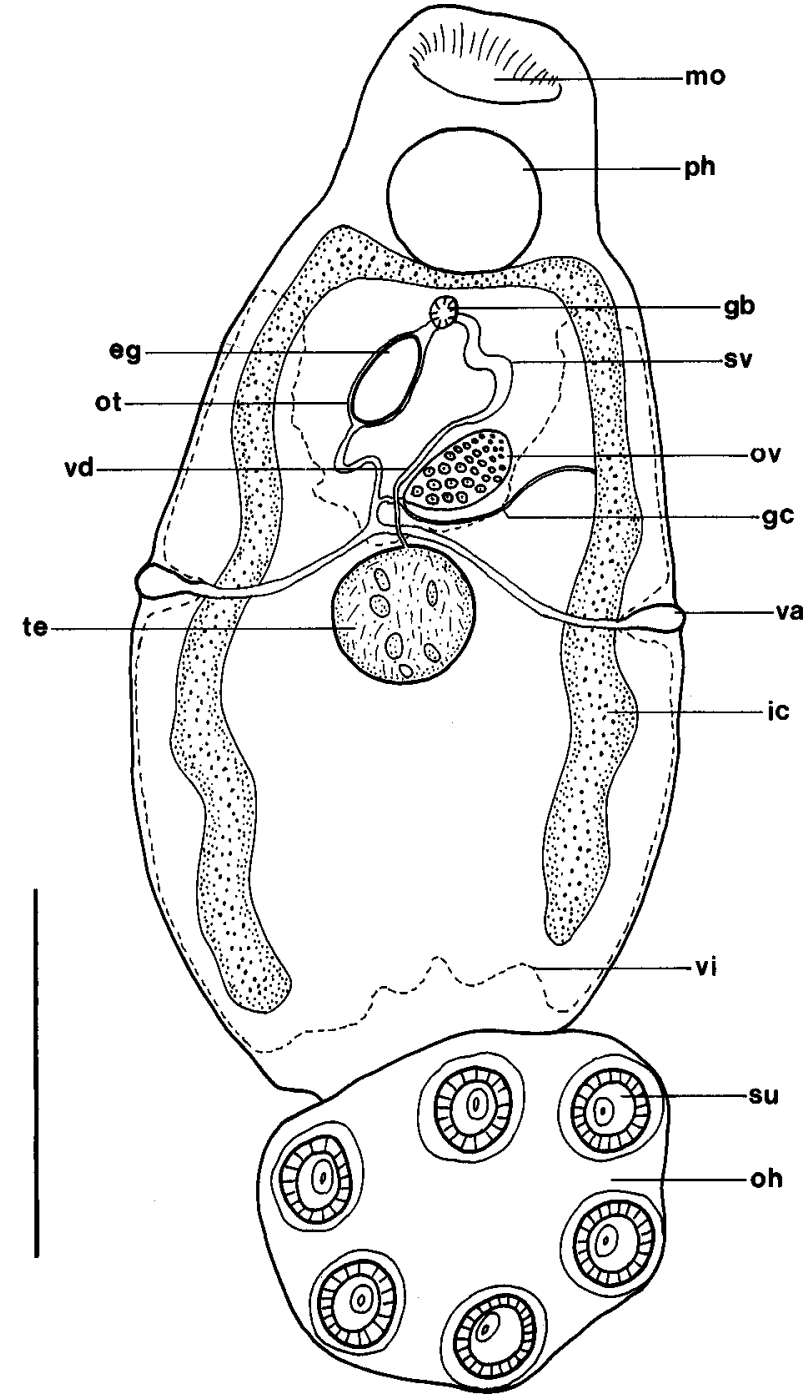

Fig. 1. Neopolystoma liewi sp. $\mathrm{n}$. Ventral view of holotype. eg - egg; gb - genital bulb; gc - genitointestinal canal; ic intestinal caecum; mo - mouth; oh - opisthaptor; ot - ootype; ov - ovary; ph - pharynx; su - sucker; sv - seminal vesicle; te - testis; va - vagina; vd - vas deferens; vi - vitelline distribution. Scale bar $=1 \mathrm{~mm}$.

Vaginae 2, lateral. Vitellaria follicular cover most of prehaptoral body except the anterior third of body.

Ovary sinistral, submedian, $287(213-339) \times 136$ (116-155); ootype well developed containing a single egg at a time. Genito-intestinal canal on same side as ovary, joins left intestinal caecum at mid-ovarian position. Uterus absent. Common genital atrium median, ventral. Genital bulb posterior to intestinal bifurcation, length 78 (63-87) and width 72 (53-92), 811 genital spines $11.8(10.8-13.2)$, sharply hooked with straight shaft and fan-shaped root.

Two types of eggs (spherical and ellipsoid) were obtained from the $250 \mu \mathrm{m}$ and the $112 \mu \mathrm{m}$ sieves respectively. Eggs collected were compared with intrauterine eggs of parasites removed. Round eggs were 
found to be eggs of Polystomoides, while the ellipsoid eggs were those of Neopolystoma liewi. Egg of N. liewi length and width $283(265-294) \times 120(109-126)$. Egg production measured over 30 days at $28^{\circ} \mathrm{C}$ was $1.5(0-3)$ eggs per parasite per $24 \mathrm{~h}$.

Oncomiracidium. The ciliated oncomiracidium resembles a typical polystomatid larva, having a narrow cylindrical body with a circular cup-shaped haptor. The haptor bears 16 marginal hooklets. Marginal hooklet 1 (postero-medial), 12.6 (12.3-12.8) in length. The ratio of total length ( $a$ in Fig. 2C) to handle length ( $b$ in Fig. 2C), 2.1 (see Murith 1981). All 8 pairs of marginal hooks are retained in adult specimens and remain the same length (Fig. 2B,C). Hooks 1 and 2 (posteromedial) are located in between the first sucker pair, hooks 3, 4 and 5 associated with suckers 1,2 and 3, respectively; hooks 6,7 and 8 located around anterior marginal region of haptor. There are no hamuli primordia present. Staining with silver nitrate revealed bands of ciliated cells on the surface of the larvae and surface sensilla. Arrangement of ciliary bands as shown in Fig. 3. There are 64 ciliated cells arranged symmetrically about the sagittal axis of the oncomiracidium in 5 cell groups recognised by Tinsley (1981) for polystomatid oncomiracidia. The number of ciliated cells in each of the cell groups is as follows: Apical group: $2 \times 1$ cell, anterior; cephalic group: $2 \times 14$ cells, dorsal, lateral and ventral; medioanterior group: $2 \times 3$ cells, ventral; medioposterior group: $2 \times 6$ cells, dorsal, lateral and ventral; haptoral group: $2 \times 8$ cells, dorsal, lateral and ventral. The same number of cells were found in both larval specimens studied.

\section{Differential diagnosis}

Neopolystoma liewi differs from all other members of the genus by possessing few and short genital spines and small marginal hooks. Its genital spines vary in number from 8 to 11 . Of the 11 specimens of $N$. liewi studied, two had 8 genital spines, two had 9, five had 10 , and two had 11. This character separates it from all other members of the genus except Neopolystoma cribbi Pichelin, 1995, which has 6-10, and Neopolystoma macleayi Rohde, 1984, which has 11-13 (Table 1). N. liewi has very short genital spines (11.8), which separates this species from the other known species for which this measurement is known including $N$. cribbi (17.8) and N. macleayi (23.6). Genital spines in a single circle compared to the two circles of larger and smaller spines found in Neopolystoma palpebrae Strelkov, 1950. The marginal hooks 1 for $N$. liewi have a length of 12.6 (12.2-12.7), which separates it from all species for which this character is known, except N. palpebrae, for which the marginal hooklet length varies between 11 and 14 (Table 1).


Fig. 2. Neopolystoma liewi sp. $\mathrm{n}$. A - genital spines drawn from holotype; B - marginal hooklets 1 from holotype; $\mathbf{C}-$ marginal hooklets 1 from oncomiracidia that hatched from eggs laid by holotype and paratypes. a - total length of marginal hooklet $1 ; \mathrm{b}$ - handle length of marginal hooklet 1 measured from tip to centre of guard base (see Murith 1981). Scale bars: A-C $=10 \mu \mathrm{m}$.

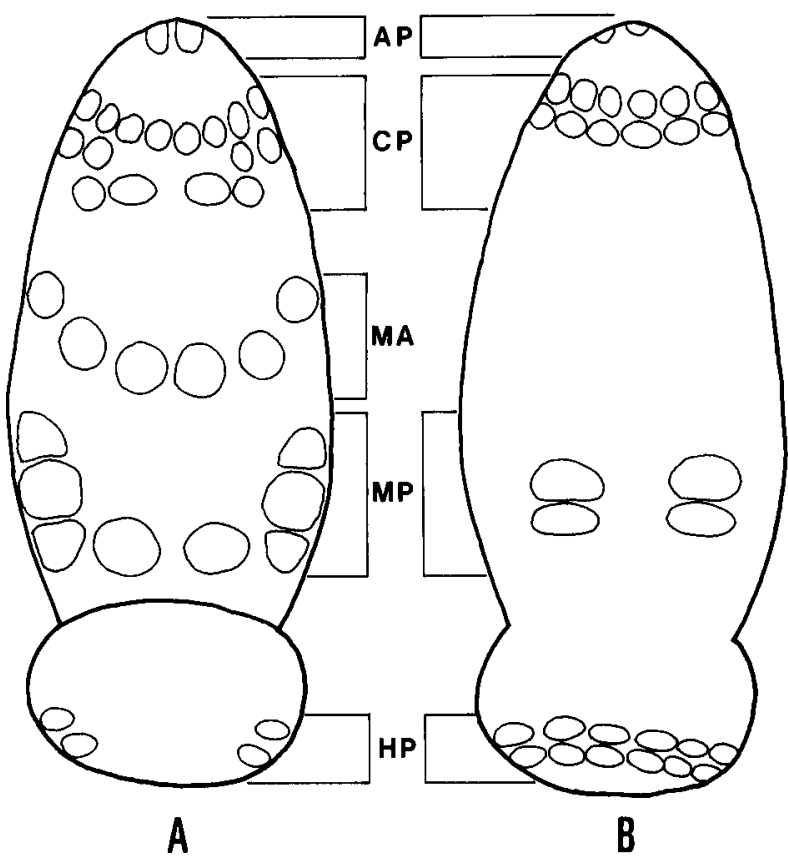

Fig. 3. Neopolystoma liewi sp. n., oncomiracidium. Ventral (A) and dorsal (B) aspects showing the distribution of ciliated cells. AP - apical group; CP - cephalic group; MA medioanterior group; MP - medioposterior group; HP haptoral group. 
Table 1. List of known species of Neopolystoma with information on the number and length of genital spines as well as the length of the marginal hooklets.

\begin{tabular}{|l|l|c|c|c|}
\hline \multicolumn{1}{|c|}{ Species } & \multicolumn{1}{|c|}{ Reference } & $\begin{array}{c}\text { Number of } \\
\text { genital spines }\end{array}$ & $\begin{array}{c}\text { Length of genital } \\
\text { spines }\end{array}$ & $\begin{array}{c}\text { Length of marginal } \\
\text { hooklet 1 }\end{array}$ \\
\hline N. chelodinae (MacCallum, 1919) & Pichelin 1995 & $14(12-16)$ & $23.8(20.8-27.2)$ & $23.8(21.6-25.6)$ \\
N. cyclovitellum Caballero, & Caballero et al. 1956 & 16 & $(19-23)$ & Not available \\
Zerecero et Grocott, 1956 & Prichelin 1995 & $8(6-10)$ & $17.8(11.2-22.4)$ & $16.5(15.2-17.6)$ \\
N. domitilae (Caballero, 1938) & Lamothe-Argumedo 1972 & $(20-21)$ & $(55-71)$ & Not available \\
N. euzeti Combes et Ktari, 1976 & Combes and Ktari 1976 & $34(33-36)$ & $(48-57)$ & Not available \\
N. exhaumatum Ozaki, 1935 & Ozaki 1935 & $(16-18)$ & Not available & Not available \\
N. kreffi Rohde, 1984 & Pichelin 1995 & $24(20-26)$ & $27.5(24-32)$ & $26.1(22.4-27.2)$ \\
N. macleayi Rohde, 1984 & Pichelin 1995 & $12(11-13)$ & $23.6(20.8-27.4)$ & $26.4(25.6-28.8)$ \\
N. novaeguineae Fairfax, 1990 & Fairfax 1990 & $32(32-33)$ & $26(23-29)$ & $23(18-26)$ \\
N. orbiculare (Stunkard, 1916) & Baruš and Moravec 1967 & $16(15-17)$ & $(45-51)$ & 21 \\
N. palpebrae Strelkov, 1950 & Strelkov 1950 & 16 & $(14-16)$ & $(11-14)$ \\
N. queenslandensis Pichelin, 1995 & Pichelin 1995 & $(22-28)$ & $21.6(19.2-25.6)$ & $17.8(16.8-19.2)$ \\
N. rugosa (MacCallum, 1919) & Price 1939 & 14 & 9 & Not available \\
N. spratti Pichelin, 1995 & Pichelin 1995 & $23(20-26)$ & $23.9(19.2-27.2)$ & $17.3(14.4-19.2)$ \\
N. terrapensis (Harwood, 1932) & Harwood 1932 & 16 & Not available & Not available \\
N. tinsleyi Pichelin, 1995 & Pichelin 1995 & $23(21-27)$ & $16.8(14.4-20.8)$ & $17.1(14.4-19.2)$ \\
\hline
\end{tabular}

\section{DISCUSSION}

The polystomatid genus Neopolystoma Price, 1939 is represented currently by 16 species. Neopolystoma palpebrae was for four and a half decades the only Neopolystoma known to infect the conjunctival cavity of a chelonian. Pichelin (1995) described four more species from the eyes of Australian chelonians: Neopolystoma cribbi was described from Emydura signata, E. macquarii, Elseya latisternum and Chelodina expansa; Neopolystoma spratti Pichelin, 1995 from Chelodina longicollis; Neopolystoma tinsleyi Pichelin, 1995 from C. expansa; and Neopolystoma queenslandensis Pichelin, 1995 from Emydura signata and E. macquarii.

Besides Neopolystoma, Cuora amboinensis also serves as host to Polystomoides and Polystomoidella (see Rohde 1963, 1965, Richardson and Brooks 1987). Polystomoides malayi was described from the urinary and accessory bladders, $P$. asiaticus from the oral cavity and Polystomoidella mayesi from the urinary bladder of C. amboinensis (see Rohde 1963). The polystomatid genus Polystomoidella is known mainly from the Nearctic region where it is represented by five species, but Richardson and Brooks (1987) described Polystomoidella mayesi from $C$. amboinensis in Malaysia. The presence of Polystomoidella in the Sunda region raises questions of possible misidentifications or a possible parasite transfer. The possibility of transfer from an introduced American turtle can only be confirmed or refuted if and when $P$. mayesi is found in this chelonian.

Polystomatids of chelonians are known to be sitespecific and in a molecular study Littlewood et al. (1997) found that congeneric species infecting the same site in different hosts are more closely related than congeneric species infecting different sites in the same host. Neopolystoma is found in the cloaca, urinary and accessory bladders, oral, pharyngeal and nasal cavities, as well as in the conjunctival cavities of freshwater chelonians (Pichelin 1995). The high degree of sitespecificity allows for speciation and could explain the three different polystomatids from $C$. amboinensis.

World-wide, chelonians have been very poorly studied for monogeneans. Africa, for example, has no less than 24 species of freshwater chelonians (Branch 1988) but only three species of polystomatids belonging to two genera are known from the Afrotropical region: Polystomoides chabaudi Euzet et Combes, 1965 from Pelomedusa subrufa in Madagascar (Euzet and Combes 1965) and Uganda (Tinsley 1973), Polystomoides bourgati Combes et Kulu, 1978 from Pelusios adansonii in Togo (Combes and Kulu 1978) and Senegal (Combes and Justine 1982) and Neopolystoma euzeti Combes et Ktari, 1976 from Clemys caspica in Tunisia (Combes and Ktari 1976). Although there are 17 species of freshwater turtles in Malaysia (Gregory and Sharma 1997), only 3 species (Cuora amboinensis, Notochelys platynota and Siebenrockiella crassicollis) have been documented to harbour polystomatids (see Combes and Rohde 1979, Rohde 1963, 1965). One would expect, given the number of chelonians in Africa and the rest of the world, that there will be many more polystomatids. Only when we know more about the diversity and geographical distribution of the turtles and their polystomatids will we be able to draw some conclusions as to how these parasites speciated and radiated. A molecular analysis of the genetic material of the parasites could shed some light on this.

The egg production for Neopolystoma liewi was found to be 1.5 eggs per worm per day. In the laboratory most eggs did not develop and only two eggs hatched 
naturally. Pichelin (1995) reported that the rate of egg production was 4.3 eggs per worm per day for Neopolystoma macleayi and 0.7 for $N$. cribbi. She also reported that eggs of $N$. cribbi failed to develop while eggs of $N$. macleayi failed to hatch naturally. In spite of the low rate of egg production, these parasites survive and manage to infect hosts successfully, indicating that they must have a very effective mode of transmission. This phenomenon together with the apparent poor success rate of egg development in the laboratory awaits further investigations.

Acknowledgements. We are indebted to: The University of the Free State (South Africa) and the University of Malaya (Malaysia) as well as the South African National Research Foundation and a R\&D grant by the Malaysian government for financial support. Mr Liew Kim-Seng George provided technical as well as field assistance.

\section{REFERENCES}

BARUŠ V., MORAVEC F. 1967: A study of the helminths from the Cuban turtle - Pseudemys decussata Gray (Emydidae). Acta Soc. Zool. Bohemoslov. 31: 313-324.

BRANCH W.R. 1988: Field Guide and Key to the Snakes and Other Reptiles of Southern Africa. Struik Publishers, Cape Town, $328 \mathrm{pp}$.

CABALLERO Y.C.E., ZERECERO Y.D.M.C., GROCOTT R.G. 1956: Helmintos de la República de Panamá. XIX. Algunos tremátodos de quelonios de aqua dulce. An. Inst. Biol. Univ. Nac. Autón. Méx. Ser. Zool. 27: 415-430.

COMBES C., JUSTINE J.-L. 1982: Présence au Sénégal de Polystomoides bourgati Combes \& Kulu, 1978 (Monogenea, Polystomatidae) chez la tortue. Bull. Inst. Fr. Afr. Noire 44: 323-324.

COMBES C., KTARI M.H. 1976: Neopolystoma euzeti n.sp. (Monogenea, Polystomatidae). Premier représentant du genre Neopolystoma Price, 1939 en Afrique. Ann. Parasitol. Hum. Comp. 51: 221-225.

COMBES C., KULU S.D. 1978: Polystomoides bourgati n.sp. (Monogenea: Polystomatidae). Premier représentant du genre Polystomoides Ward, 1917 en Afrique Occidentale. Rev. Zool. Afr. 92: 622-626.

COMBES C., ROHDE K. 1979: Polystomoides platynotae n.sp. (Monogenea, Polystomatidae), parasite du chélonien d'eau douce Notochelys platynotae (Gray, 1834) en Malaisie. Vie Milieu 28-29: 69-75.

EUZET L., COMBES C. 1965: Parasites des chéloniens Malgasches. Polystomoides chabaudi n.sp. (Monogenea) chez la tortue d'eau douce Pelomedusa subrufa Lacépède, 1788. Ann. Parasitol. Hum. Comp. 40: 445-450.

FAIRFAX R.A. 1990: A new species of Neopolystoma (Monogenea) and the occurrence of Polystomoides sp. in New Guinea, with notes on some polystomes from NorthEast Australia. Sci. New Guinea 16: 109-114.

GREGORY R., SHARMA D.S.K. 1997: Review of legislation affecting marine and freshwater turtle, terrapins and tortoise conservation and management in Malaysia: recommendations for change. Report produced under Project MYS343/96. WWF Publications. 45 pp.

HARWOOD P.D. 1932: The helminths parasitic in the Amphibia and Reptilia of Houston, Texas, and vicinity. Proc. U.S. Nat. Mus. 81: 1-71.

LAMOTHE-ARGUMEDO R. 1972: Monogéneos de reptiles 1. Redescriptión de cuatro especiés de Monogenea (Polystomatidae) parásitos de la vejiga urinaria de tortugas, de México. An. Inst. Biol. Univ. Nac. Autón. Méx. Ser. Zool. 1: 1-16.
LITTLEWOOD D.T.J., ROHDE K., CLOUGH K.A. 1997: Parasite speciation within or between host species? Phylogenetic evidence from site-specific polystome monogeneans. Int. J. Parasitol. 27: 1289-1297.

LYNCH J.E. 1933: The miracidium of Heronimus chelydrae MacCallum. Q. J. Microsc. Sci. 76: 13-33.

MURITH D. 1981: Contribution a l'étude de la systématique des polystomes (Monogènes, Polystomatidae) parasites d'amphibiens anourens de basse Côte-d'Ivoire. Rev. Suisse Zool. 88: 475-533.

OZAKI Y. 1935: Studies on the frog trematode, Diplorchis ranae. I. Morphology of the adult form with a review of the family Polystomatidae J. Sci. Hiroshima Univ. Ser. B I (Zool.) 3: 193-225.

PICHELIN S. 1995: The taxonomy and biology of the Polystomatidae (Monogenea) in Australian freshwater turtles (Chelidae, Pleurodira). J. Nat. Hist. 29: 1345-1381.

PRICE E.W. 1939: North American monogenetic trematodes. IV. The family Polystomatidae (Polystomatoidea). Proc. Helminthol. Soc. Wash. 6: 80-92.

REICHENBACH-KLINKE H. 1966: Eine neue Art der Polystomatidengattung Eupolystoma Kaw, 1950 (Monogenea: Polystomatidae) von den Kiemen des australischen Lungenfisches Neoceratodus forsteri Krefft. Zool. Anz. 176: 142-146.

RICHARDSON J.P.M., BROOKS D.R. 1987: Polystomoidella mayesi n.sp. (Monogenea: Polystomatidae) from the urinary bladder of a Malaysian box turtle, Cuora amboinensis. Can. J. Zool. 65: 1567-1569.

ROHDE K. 1963: Polystomoides malayi n.sp. (Monogenea, Polystomatidae) aus der Harnblase von Cyclemys amboinensis in Malaysia. Z. Parasitenkd. 22: 278-282.

ROHDE K. 1965: Studies on the genus Polystomoides Ward, 1917 (Monogenea). Description of 4 Malayan species, a key to the known species, and a comparison of the subcuticular layers in Polystomoides and some digenetic trematodes. Zool. Jahrb. Abt. Syst. Oekol. Geogr. Tiere 92: 345-368.

STRELKOV Yu.A. 1950: A new species of monogenetic trematode from Amyda sinensis. Dokl. Akad. Nauk SSSR Ser. Biol. 74: 159-162. (In Russian.)

STUNKARD H.W. 1924: A new trematode, Oculotrema hippopotami n.g., n.sp., from the eye of the hippopotamus. Parasitology 16: 436-440.

TINSLEY R.C. 1973: Observations on Polystomatidae (Monogenoidea) from East Africa with a description of Polystoma makereri n.sp. Z. Parasitenkd. 42: 251-263. 
TINSLEY R.C. 1981: The evidence from parasite relationships for the evolutionary status of Xenopus (Anura: Pipidae). Monit. Zool. Ital. 15: 367-385.
YAMAGUTI S. 1963: Systema Helminthum, Volume IV. Interscience, New York, 699 pp.

Accepted 17 September 1999

\section{Fourth International Symposium on Monogenea}

9-13 July 2001

Brisbane, Queensland, Australia

Organised by the Department of Microbiology \& Parasitology, The University of Queensland

Venue:

The Women's College of The University of Queensland

Contact:

Dr. Ian D. Whittington or Dr. Leslie A. Chisholm

Department of Microbiology \& Parasitology

The University of Queensland

Brisbane, Queensland 4072

Australia

Fax: ++61 733654620

E-mail: i.whittington@mailbox.uq.edu.au or 1.chisholm@mailbox.uq.edu.au http://www.biosci.uq.edu.au/micro/academic/ianw/ism4.htm 